Pengaruh Supervisi Klinik Model

Akademik Terhadap Kemampuan

Perawat Dalam Menerapkan Patient

Centered Care (PCC) Di Rumah Sakit
NURSCOPE

Jurnal Keperawatan dan Pemikiran IImiah

Atmaja, A.D. (2018). Pengaruh Supervisi Klinik

Model Akademik Terhadap Kemampuan Perawat

Dalam Menerapkan Patient Centered Care (PCC) Di

Rumah Sakit.

Nurscope.Jurnal Keperawatan Pemikiran IImiah.

$4(6) .41-54$

\author{
Arifin Dwi Atmaja ${ }^{1}$, MC. Inge Hartini ${ }^{2}$, Luky Dwiantoro ${ }^{3}$ \\ ${ }^{1}$ STIKES BHAMADA Slawi \\ ${ }^{2}$ Rumah Sakit St Elisabet Semarang \\ ${ }^{3}$ Universitas Diponegoro
}

\begin{abstract}
Abstrak
Pendahuluan: Patient Centered Care (PCC) yang berkualitas akan meningkatkan mutu asuhan keperawatan, kemandirian pasien, kualitas hidup pasien, self efficacy pasien, dan dapat mengurangi angka kekambuhan, menurunkan LOS (Length of Stay) dan menekan biaya perawatan. Supervisi Klinik Model Akademik merupakan suatu metode untuk meningkatkan profesionalisme dalam pemberian asuhan keperawatan. Tujuan adalah untuk mengetahui pengaruh supervisi klinik Model Akademik oleh kepala ruang terhadap kemampuan perawat pelaksana dalam menerapkan Patient Centered Care di rumah sakit. Penelitian dilakukan dengan metode Quasy experimental pre-post test with control group. Jumlah sampel adalah 51 perawat. Pengambilan sampel dilakukan dengan teknik sampel tanpa peluang (non probability sampling). Analisis statistik yang digunakan adalah oneway ANOVA. Hasil penelitian menunjukan supervisi klinik model akademik kepala ruang mempunyai pengaruh yang signifikan untuk meningkatkan penerapan patient centered care. Supervisi Klinik Model Akademik adalah kompetensi yang harus dimiliki oleh manajer keperawatan. Disarankan bagi kepala ruang untuk memberikan pengarahan dan bimbingan melalui supervisi secara terus menerus untuk mempertahankan dan meningkatkan kualitas patient centered care.
\end{abstract}

Kata Kunci: Patient centered care, supervisi klinik model akademik

\title{
The Effects Of Clinical Supervision Of Academic Model To Improve The Ability Of Nurses In Applying Patient-Centered Care (PCC) At Hospital
}

\begin{abstract}
Introduction: Quality patient centered care will improve the quality of nursing care and the patients independence, life quality, and self-efficacy. It also reduces the rate of disease recurrence, the length of stay (LOS), and the cost of care. Clinical supervision of academic model is a method to increase professionalism in the delivery of nursing care. The purpose of this study was to determine the effects of clinical supervision academic model of head nurses on the quality of discharge planning. The study represented a pre-post test quasi-experimental design with a control group. The population was all nurses in Mitra Siaga hospital. The samples were 51 nurses selected by non-probability sampling. The statistical analysis used was one-way ANOVA. The results showed that the clinical supervision of academic model of the head nurses had a significant effect on improving the ability of nurse in applying patient centered care. Clinical supervision of academic model is a competence that nursing managers should have; therefore, it is suggested that head nurses provide guidance and supervision continuosly to maintain and improve the quality of patient centered care.
\end{abstract}

Keywords: patient centered care, clinical supervision of academic model

Corresponding Author:

STIKES BHAMADA SLAWI JI. Cut Nyak Dhien no. 16 Kalisapu, Slawi 52416

email: arifindwiatmaja@gmail.com 


\section{PENDAHULUAN}

Patient Centered Care (PCC) merupakan paradigma pelayanan kesehatan yang menempatkan pasien pada center of care Sebagai pedoman, PCC lebih menghargai sentuhan dan tidak hanya sekedar berbicara dengan pasien. PCC tidak hanya mengedepankan teknologi, tapi lebih memperhatikan pentingnya interaksi diantara individu. Konsep PCC pertama kali oleh Harvey Picker pada tahun 1988 melalui Picker Institute di Inggris. Menurut Picker Institute dalam Patient Centered Care Improvement Guide, empat prinsip dari PCC antara lain: dignity and respect, information sharing, participation, dan collaboration (Frampton, 2008). Bila di tinjau dari komponen-komponennya, PCC lebih mengedepankan nilai pasien sebagai individu, memberikan dukungan secara emosional dan memberikan kenyamanan fisik, memperhatikan kebutuhan pasien mulai dari masuk rumah sakit sampai dengan perawatan lanjutan yang diperlukan, serta memberikan informasi dan edukasi pada setiap pasien.

Keuntungan dari implementasi PCC antara lain: pasien sebagai pusat pelayanan asuhan keperawatan dan aktifitas, sehingga pemberian pelayanan lebih efektif dengan orang yang tepat dan waktu yang tepat; meningkatkan kontinuitas perawatan dan integrasi tenaga kesehatan profesional dalam berkolaborasi untuk kepentingan pasien mereka, dengan meminimalisir perpindahan pasien ke rumah sakit lain. Selain itu, PCC juga dapat meningkatkan otonomi pasien dan pemberdayaan anggota staf untuk merencanakan dan menjalankan pekerjaan mereka sesuai dengan kebutuhan pasien (Frampton, 2008).

Strategi-strategi yang dapat dilakukan dalam implementasi PCC yaitu: pelatihan leadership, pemberian reward dan insentif dan pelatihan untuk quality improvement (Drenkard, 2013).

Pelatihan PCC efektif terhadap peningkatan penerapan PCC dilihat dari persepsi pasien walaupun hasil yang diperoleh kurang memuaskan. Maka perlu upaya monitoring dari manager rumah sakit untuk memantau pelaksanaan PCC di rumah sakit (Rusmawati, 2016).

Supervisi merupakan salah satu bentuk pengawasan yang dilakukan di ruang rawat inap. Pelaksanaan supervisi mempunyai dampak yang positif kepada peningkatan profesionalitas dan akuntabilitas staf. Hal ini diperkuat bahwa supervisi sebagai kegiatan pengawasan kualitas pelayanan oleh supervisor ruangan (Nursalam, 2015). Kegiatan penjaminan kualitas asuhan keperawatan dapat dilakukan melalui kegiatan supervisi berjenjang kepada staf (Keliat, 2012). Pengawasan mengacu pada standar sebagai tolok ukur untuk penilaian kualitas pelayanan yang diberikan. Supervisi klinis efektif untuk membantu peningkatan kualitas perawatan pasien (Davis, 2011).

Supervisi klinis keperawatan sangat diperlukan dalam tatanan praktek keperawatan mengingat pelayanan keperawatan yang profesional perlu dijaga, dimonitor, dievaluasi sehingga menjadi lebih baik. Supervisi merupakan intervensi manajemen yang sangat berharga untuk mencapai tujuan, adapun tujuan yang diharapkan adalah adanya perbaiki kinerja (Uys, 2005; Gillies, 1996). Model supervisi klinis yang paling banyak digunakan dalam profesi keperawatan adalah supervisi model akademik yang di populerkan oleh Farington, yang terdiri dari 3 (tiga) kegiatan yaitu educative, supportive, dan managerial (Farrington, 1995).

Keunggulan supervisi klinis model akademik adalah dapat mempermudah perawat untuk latihan dalam menghadapi isu-isu yang terkait, sebagai sarana bertukar pikiran atau pendapat, konsistensi dalam menerapkan standar yang ada, dan meningkatkan kualitas kinerja (Lynch, 2009). Supervisi klinis dilakukan terbukti mengakomodir dukungan rekan kerja dan menghilangkan stress bagi perawat (fungsi dukungan), sarana memperkenalkan tanggung jawab praktik profesional (fungsi manajerial) dan pengembangan pengetahuan, sikap, serta keterampilan secara berkelanjutan (Brunero, 2008; Sloan, 2002). 
RSU Mitra Siaga Tegal merupakan rumah sakit tipe $\mathrm{C}$ dan merupakan rumah sakit yang sedang berkembang di Kabupaten Tegal khususnya bagian utara dengan kapasitas tempat tidur ruang rawat inap sebanyak 125 buah serta jumlah perawat sebanyak 102 orang. Hasil wawancara yang dilakukan peneliti terhadap kepala bidang keperawatan dan kepala seksi keperawatan Rumah Sakit Mitra Siaga Tegal diperoleh informasi bahwa supervisi keperawatan pada tingkat rumah sakit dilakukan oleh pejabat sesuai struktur organisasi yang ada pada jam kerja normal yaitu shift pagi. Kegiatan supervisi masih dilakukan secara situasional yaitu apabila ada masalah, terutama untuk masalah layanan kesehatan secara umum, baik yang dilaporkan oleh kepala ruang, rekan perawat lain atau berasal dari pasien. Supervisi langsung yang dilakukan secara khusus untuk layanan keperawatan belum dilaksanakan secara rutin, dan masih berorientasi pada paradigma lama yang belum menyentuh pada pemberian bimbingan, dukungan dan manajerial. Supervisi tidak langsung berupa laporan adanya penyimpangan, atau komplain dari pasien tentang layanan keperawatan, belum tercatat dengan baik dan belum ada buku khusus untuk mendokumentasikannya.

\section{METODE}

Jenis penelitian yang digunakan dalam penelitian ini adalah penelitian kuantitatif dengan rancangan quasy experimental pre-post test control group. Populasi penelitian ini adalah seluruh perawat pelaksana RS Mitra Siaga Tegal sejumlah 102 orang. Sample penelitian dengan cara purposive sampling 26 perawat kelompok intervensi dan 25 perawat kelompok kontrol

\section{HASIL}

\section{a. Kemampuan Supervisi Klinik Model Akademik}

Pelaksanaan supervisi klinik model akademik sebelum dan setelah dilakukan pelatihan disajikan dalam bentuk tabel sebagai berikut:

Table 1 Kemampuan supervisi klinik model akademik RSU Mitra Siaga Tegal, bulan Juni tahun 2017, $\mathrm{n}=5$ responden

\begin{tabular}{lccccc}
\hline \multicolumn{1}{c}{ Karakteristik } & Mean & Median & S.D & Min-Max \\
\hline $\begin{array}{l}\text { Kemampuan supervisi } \\
\text { dilakukan intervensi }\end{array}$ & sebelum & & & & \\
- Kelompok Intervensi & & 20,00 & 20,00 & 1.000 & $19-21$ \\
- Kelompok Kontrol & & 17,50 & 17,50 & 0,707 & $17-18$ \\
\hline Kemampuan supervisi & setelah & & & & \\
dilakukan intervensi & & & & & \\
$-\quad$ Kelompok Intervensi & & 23,33 & 24,00 & 2,082 & $21-25$ \\
- Kelompok Kontrol & 18,50 & 18,50 & 0,707 & $18-19$ \\
\hline
\end{tabular}

Hasil analisa dalam tabel 1 menggambarkan bahwa kemampuan supervisi pada kelompok intervensi sebelum dilakukan pelatihan supervisi klinik model akademik kepala ruang (nilai pre-test) adalah 20,00 setelah dilakukan pelatihan dan pendampingan terjadi peningkatan nilai rerata menjadi 23,33 . Jadi peningkatan nilai reratanya adalah 3,33 . Kelompok kontrol dalam penelitian ini juga mengalami peningkatan kemampuan supervisi yaitu dari nilai 17,50 menjadi 18,50 dengan peningkatan reratanya 1,0 .

b. Pelaksanaan Patient Centered Care

Pelaksanaan Patient Centered Care sebelum dan setelah dilakukan pelatihan disajikan dalam bentuk tabel sebagai berikut:

Table 2 Pelaksanaan Patient Centered Care RSU Mitra Siaga Tegal, bulan Juni tahun 2017, $\mathrm{n}=51$ responden 


\begin{tabular}{lccccc}
\hline \multicolumn{1}{c}{ Karakteristik } & Mean & Median & S.D & Min-Max & p-value \\
\hline $\begin{array}{l}\text { Pelaksanaan Patient Centered } \\
\text { Care sebelum dilakukan intervensi }\end{array}$ & & & & & \\
$-\quad$ Kelompok Intervensi & & & & & \\
$-\quad$ Kelompok Kontrol & 31,46 & 32 & 1,36 & $28-33$ & 0,005 \\
& 31,52 & 31 & 1,75 & $28-35$ & 0,233 \\
\hline $\begin{array}{l}\text { Pelaksanaan Patient Centered } \\
\text { Care setelah dilakukan intervensi }\end{array}$ & & & & & \\
$-\quad$ Kelompok Intervensi & 42,65 & 43 & 1,36 & $37-45$ & 0,018 \\
$-\quad$ Kelompok Kontrol & 35,32 & 36 & 1,85 & $32-37$ & 0,022 \\
&
\end{tabular}

Hasil analisa dalam tabel 2 menggambarkan bahwa penerapan Patient Centered Care pada kelompok intervensi sebelum dilakukan pelatihan supervisi klinik model akademik kepala ruang (nilai pre-test) adalah 31,46 setelah dilakukan pelatihan dan pendampingan terjadi peningkatan nilai rerata menjadi 42,65 . Jadi peningkatan nilai reratanya adalah 11,19. Kelompok kontrol dalam penelitian ini juga mengalami peningkatan penerapan Patient Centered Care yaitu dari nilai 31,52 menjadi 35,32 dengan peningkatan reratanya 3,8 .

c. Uji normalitas data

Table 3 Uji Normalitas Data Pelaksanaan Patient Centered Care Di RSU Mitra Siaga Tegal Tahun 2017

\begin{tabular}{lc}
\hline \multicolumn{1}{c}{ Variable } & $\boldsymbol{p}$-value \\
\hline Pelaksanaan Patient Centered Care Sebelum dilakukan intervensi & \\
$-\quad$ Kelompok Intervensi & 0,005 \\
$-\quad$ Kelompok Kontrol & 0,233 \\
& \\
Pelaksanaan Patient Centered Care Setelah dilakukan intervensi & \\
$-\quad$ Kelompok Intervensi & 0,018 \\
$-\quad$ Kelompok Kontrol & 0,022 \\
\hline
\end{tabular}

Hasil uji normalitas menggunakan Shapiro Wilk diketahui bahwa sebaran data pelaksanaan patient center care kelompok kontrol sebelum dilakukan intervensi memiliki sebaran data normal $(p$-value $>0,05)$ dan variabel lain memiliki sebaran data tidak normal ( $p$-value $<0,05)$.

d. Uji homogenitas data

Table 4 Uji Homogenitas berdasarkan Umur dan Masa kerja Responden Di RSU Mitra Siaga Tegal Tahun 2017

\begin{tabular}{llll}
\hline \multicolumn{1}{c}{ Karakteristik } & Mean & Min-Max & S.D \\
\hline Umur Responden & & & \\
$-\quad$ Kelompok Intervensi & 29,23 & $22-52$ & 8,228 \\
- Kelompok Kontrol & 30,04 & $22-52$ & 8,580 \\
\hline Masa Kerja Responden & & & \\
- Kelompok Intervensi & 5,03 & $0-28$ & 7,720 \\
- Kelompok Kontrol & 5,91 & $0-28$ & 8,311 \\
\hline
\end{tabular}

Hasil uji homogenitas menggunakan Levene diketahui bahwa sebaran data karakteristik umur responden 0,253 dan masa kerja responden 0,276 ( $p$-value>0,05) artinya bahwa responden baik kelompok intervensi atau kelompok kontrol datanya homogen.

e. Pengaruh supervisi klinik model akademik terhadap penerapan Patient Centered Care 
Pengaruh perlakuan supervisi klinik model akademik dinilai dengan cara membedakan penerapan Patient Centered Care pada kelompok intervensi dengan kelompok kontrol.

Table 5 Uji beda rerata pelaksanaan Patient Centered Care Di RSU Mitra Siaga Tegal 2017

\begin{tabular}{lccc}
\multicolumn{1}{c}{ Variabel } & \multicolumn{2}{c}{ Rata-rata } & P Value \\
\cline { 2 - 4 } & $\begin{array}{c}\text { Intervensi } \\
\text { (n=26) }\end{array}$ & $\begin{array}{c}\text { Kontrol } \\
\text { (n=25) }\end{array}$ & \\
\hline $\begin{array}{l}\text { Pelaksanaan PCC sebelum dilaksanakan } \\
\text { pelatihan supervisi }\end{array}$ & 31,46 & 31,52 & 0,714 \\
$\begin{array}{l}\text { Pelaksanaan PCC setelah dilaksanakan } \\
\text { pelatihan supervisi }\end{array}$ & 42,65 & 35,32 & 0,000 \\
$\begin{array}{l}\text { Perubahan pelaksanaan PCC sebelum dan } \\
\text { setelah dilaksanakan pelatihan supervisi }\end{array}$ & 11,19 & 3,8 & 0,000 \\
\hline
\end{tabular}

Hasil analisa dalam tabel 5 menggambarkan bahwa penerapan Patient Centered Care pada kelompok intervensi sebelum dilakukan pelatihan supervisi klinik model akademik kepala ruang (nilai pre-test) adalah 31,46 setelah dilakukan pelatihan dan pendampingan terjadi peningkatan nilai rerata menjadi 42,65 . Jadi peningkatan nilai reratanya adalah 11,19. Kelompok kontrol dalam penelitian ini juga mengalami peningkatan penerapan Patient Centered Care yaitu dari nilai 31,52 menjadi 35,32 dengan peningkatan reratanya 3,8 . Dengan nilai $p$-value $>0,05$ pada pelaksanaan PCC sebelum pelatihan baik kelompok intervensi maupun kontrol dengan nilai 0,714 artinya ada perubahan tetapi kecil sehingga tidak signifikan dan nilai $p$-value $<0,05$ pada pelaksanaan PCC setelah pelatihan baik kelompok intervensi maupun kontrol dengan nilai 0,000 artinya ada perubahan secara signifikan.

f. Perubahan penerapan Patient Centered Care sebelum dan setelah dilakukan supervisi klinik model akademik

Perubahan penerapan Patient Centered Care dinilai untuk mengetahui efektifitas supervisi klinik model akademik terhadap penerapan Patient Centered Care di RSU Mitra Siaga Tegal.

Table 6 Uji beda rerata pelaksanaan Patient Centered Care sebelum dan setelah dilakukan intervensi Di RSU Mitra Siaga Tegal 2017

\begin{tabular}{|c|c|c|c|c|c|}
\hline \multirow{2}{*}{\multicolumn{3}{|c|}{ Variabel }} & \multicolumn{2}{|c|}{ Rata-rata } & \multirow[t]{2}{*}{ P Value } \\
\hline & & & Pre & Post & \\
\hline $\begin{array}{l}\text { Pelaksanaan Patient } \\
\text { Kelompok Intervensi }\end{array}$ & Centered & Care & 31,46 & 42,65 & 0,000 \\
\hline $\begin{array}{l}\text { Pelaksanaan Patient } \\
\text { Kelompok Kontrol }\end{array}$ & Centered & Care & 31,52 & 35,32 & 0,000 \\
\hline
\end{tabular}

Hasil uji statistik diketahui bahwa kedua kelompok memiliki p-value $<0,05)$, sehingga dapat disimpulkan bahwa kelompok intervensi dan kelompok kontrol memiliki kenaikan nilai pelaksanaan PCC secara signifikan.

\section{PEMBAHASAN}

a. Perbedaan Kemampuan Supervisi Klinis Sebelum dan Sesudah Pelatihan Supervisi Klinis Model Akademik pada Kelompok Intervensi dan Kelompok Kontrol

Supervisi klinis merupakan sebuah proses profesional yang dilakukan oleh supervisor melalui proses pengarahan, pembimbingan dan evaluasi kepada supervisi secara terus menerus sehingga tercapai kualitas pelayanan yang optimal. Supervisi klinik model akademik salah satu metoda yang efektif dalam melakukan pengarahan dan pembimbingan untuk meningkatkan kinerja (Serio, 2014). Seorang kepala ruang harus 
mempunyai kemampuan supervisi klinik model akademik untuk mengembangkan keterampilan praktik dan kompetensi perawat sehingga meningkatkan kinerja individu dan organisasi.

Hasil analisis kemampuan supervisi klinis sebelum diberikan pelatihan supervisi klinis Model Akademik pada kelompok intervensi dan kelompok kontrol menunjukkan hasil yang kurang baik. Hasil analisis menunjukkan bahwa kemampuan supervisi klinis sebelum diberikan perlakuan pada kelompok intervensi memiliki rentang nilai $19-21$ dengan nilai rata-rata 20,00 sehingga masih diperlukan peningkatan nilai 80,00 untuk mencapai nilai maksimal kemampuan supervisi klinis oleh supervisor ruangan.

Hasil observasi langsung terkait kemampuan supervisi klinis pada kelompok intervensi sebelum diberikan perlakuan menunjukkan bahwa sebagian besar supervisor ruangan tidak sesuai dengan panduan dalam melakukan tindakan supervisi klinis, misalnya supervisi klinis dilakukan: 1) tidak terjadwal, 2) tidak jelas sasaran, 3) tidak terdapat umpan balik, 4) tidak terdokumentasi 5) tidak berkelanjutan, sehingga supervisi klinis yang dilakukan tidak dapat memberikan informasi yang objektif terkait pelaksanaan kegiatan berdasarkan suatu standar yang telah ditetapkan.

Hasil analisis pada kelompok intervensi setelah diberikan pelatihan supervisi klinis Model Akademik kepada supervisor ruangan, terjadi peningkatan nilai rata-rata sebesar 3,33 dengan nilai rata-rata 23,33 dengan rentang nilai $21-25$, sehingga masih diperlukan peningkatan nilai 76,67 untuk mencapai nilai maksimal terkait kemampuan supervisi klinis. Hasil ini walaupun tidak mencapai nilai sempurna, akan tetapi rata-rata mengalami peningkatan nilai sebesar 3,33 dari nilai awal.

Hasil observasi langsung terkait kemampuan supervisi klinis pada kelompok intervensi sesudah diberikan perlakuan menunjukkan sebagian besar supervisor ruangan memperlihatkan kesesuaian dengan panduan yang dibuat dalam melakukan supervisi klinis, misalnya supervisi klinis dilakukan secara 1) terjadwal, 2) jelas sasarannya, 3) terdapat umpan balik, 4) terdokumentasi 5) berkelanjutan, sehingga supervisi klinis yang dilakukan dapat memberikan informasi yang objektif terkait pelaksanaan kegiatan berdasarkan suatu standar yang telah ditetapkan.

Hasil yang hampir sama didapatkan pada hasil analisis sebelum perlakuan pada kelompok kontrol yang menunjukkan bahwa kemampuan supervisi klinis tidak sesuai dengan panduan yaitu memiliki rentang nilai $17-18$ dengan nilai rata-rata 17,50 sehingga masih diperlukan peningkatan 82,50 untuk mencapai nilai maksimal kemampuan supervisi klinis oleh supervisor ruangan.

Hasil analisis pada kelompok kontrol yang diukur saat bersamaan sesudah kelompok intervensi mendapatkan pelatihan menunjukkan bahwa kemampuan supervisi klinis memiliki rentang nilai $18-19$ dengan nilai rata-rata 18,50 . Hal ini menunjukkan tidak terlalu signifikannya perubahan yang terjadi jika dibandingkan dengan data hasil pengukuran awal karena hanya mengalami peningkatan nilai sebesar 1.00 dari nilai awal. Hal ini disebabkan supervisor ruangan hanya mendapatkan panduan pelaksanaan tanpa dilakukan pelatihan serta pendampingan dalam pelaksanaannya.

Hal ini membuktikan bahwa pelatihan yang dilakukan yaitu tentang supervisi klinis Model Akademik efektif untuk meningkatkan kemampuan supervisi klinis supervisor ruangan. Sesuai dengan yang dikemukakan oleh Dedi Kurniadi bahwa pelatihan akan meningkatkan 
penguasaan keterampilan dan keahlian (Kurniadi, 2007). Siagian menyatakan bahwa pelatihan dapat membantu perawat untuk bekerja dengan baik, berperilaku lebih baik, dan mampu meningkatkan rasa percaya diri (Siagian, 2009). Sejalan dengan UndangUndang no 36 tahun 2009 tentang kesehatan menjelaskan bahwa dalam pengembangan keahlian dan kewenangan secara terus menerus harus ditingkatkan mutunya melalui pendidikan berkelanjutan salah satunya adalah pelatihan (Kemenkes $\mathrm{RI}, 2009$ ).

Perbedaan hasil analisis antara kelompok intervensi dan kelompok kontrol menunjukkan bahwa kelompok intervensi dan kelompok kontrol memberikan respon yang berbeda berdasarkan ada atau tidak adanya stimulus berupa pelatihan supervisi klinis Model Akademik. Hal ini menunjukkan bahwa melalui pelatihan supervisi klinis Model Akademik terbukti efektif untuk meningkatkan kemampuan supervisor ruangan dalam melakukan supervisi klinis.

Supervisor ruangan dalam bekerja memerlukan kecakapan dalam kognitif, afektif dan psikomotor, hal ini dapat dicapai dengan mengikuti pendidikan dan pelatihan. Menurut analisa peneliti, supervisor ruangan perlu mendapatkan pendidikan atau pelatihan yang bersifat khusus untuk dapat melakukan kegiatan supervisi klinis dengan efektif karena supervisor ruangan membutuhkan pengetahuan yang baik, diantaranya yaitu komunikasi, motivasi, bimbingan, pengarahan, kepemimpinan, dan pengalaman sehingga dapat melaksanakan supervisi klinis dengan baik dan sesuai tujuan. Hal ini dibuktikan oleh hasil penelitian Widiyanto dan Syaifullah tentang kepala ruang atau juga supervisor yang mendapatkan pelatihan supervisi klinis terbukti meningkatkan kemampuan dalam kegiatan supervisi klinis (Saifulloh, 2009; Widiyanto, 2012). Pelatihan yang dilakukan berperan penting bagi suatu organisasi untuk meningkatkan kemampuan manajer sehingga mampu menjalankan tugas dan fungsinya dengan baik (Sulistyani, 2009). Kemampuan supervisi klinis bagi supervisor ruangan perlu dikembangkan melalui pelatihan supervisi yang akan meningkatkan kemampuan kognitif, afektif dan psikomotor sehingga akan diperoleh peningkatan produktivitas atau hasil yang sesuai tujuan. Pelatihan supervisi klinis memberikan perubahan yang baik, hal ini ditunjukkan dengan adanya perubahan pengetahuan supervisor ruangan setelah pelatihan dengan nilai post test mendapatkan nilai hampir sempurna dengan evaluasi hasil praktik supervisi semuanya dinyatakan lulus. Hal ini menurut peneliti menunjukkan bahwa pelatihan supervisi klinis menjadi bagian penting untuk meningkatkan kemampuan supervisor ruangan dalam melaksanakan supervisi klinis dengan baik.

b. Pengaruh Pelatihan Supervisi Klinis Model Akademik terhadap Peningkatan Kemampuan Supervisi Klinis

Hasil analisis menunjukkan bahwa pada kelompok intervensi terjadi peningkatan nilai rata-rata 3,33, sedangkan pada kelompok kontrol peningkatan nilai rata-rata hanya 1,00. Hal ini membuktikan ada pengaruh pelatihan supervisi klinis Model Akademik yang diberikan kepada supervisor ruangan terhadap kemampuan supervisi klinis di RSU Mitra Siaga Tegal.

Pelatihan yang dilakukan membantu supervisor ruangan untuk mengembangkan kemampuan kognitif, afektif dan psikomotor dalam melaksanakan supervisi klinis Model Akademik. Menurut peneliti, pelatihan yang dilakukan mempunyai tujuan untuk meningkatkan kemampuan supervisor dalam menjalankan tugas pokoknya yaitu melaksanakan supervisi klinis terhadap perawat di ruangan demi terciptanya iklim kerja yang kondusif dan saling mendukung serta memotivasi.

Menurut Hasibuan, pelatihan adalah suatu usaha meningkatkan kemampuan teknis, 
teoritis dan konseptual dan moral karyawan sesuai dengan kebutuhan pekerjaan atau jabatan melalui pendidikan dan pelatihan (Hasibuan, 2006). Menurut Bella dalam Hasibuan, pendidikan dan latihan sama dengan pengembangan yaitu proses meningkatkan keterampilan kerja baik teknis maupun manajerial. Indikator keberhasilan suatu pelatihan salah satunya bisa dilihat dari prakarsa karyawan yang dilatih, setelah mengikuti pelatihan harapannya karyawan dalam melakukan secara mandiri apa yang telah diajarkan dan berusaha mengembangkan kreativitasnya (Siagian, 2009).

Supervisor yang dilatih dalam penelitian ini melakukan kegiatan supervisi klinis Model Akademik kepada staf perawat selama 4 minggu. Waktu 4 minggu memang masih terlalu dini untuk dapat menerima perubahan perilaku menjadi optimal, seseorang yang dari tidak tahu menjadi tahu, yang pada akhirnya berdampak pada perubahan perilaku dalam memberikan pelayanan kepada pasien. Pada pelaksanaannya supervisor ruangan belum mengeksplorasi seluruh kemampuan yang dimiliki pada pelaksanaan supervisi klinis karena dibatasi oleh tenggang waktu penelitian.

Sesuai dengan teori perubahan dari Lewin yang mengemukakan bahwa seseorang untuk bergerak (moving) ke dalam keadaan yang baru (Marquis, 2012). Supervisor ruangan yang mempunyai kebutuhan informasi untuk mengetahui tahap-tahap berubah yaitu dengan cara pemberian informasi yang baik, pendampingan dalam pelaksanaan, membantu dalam penyelesaian masalah serta dilakukan umpan balik dan upaya pembinaan secara terus-menerus terhadap perawat yang disupervisi. Maka dari itu perlu diperhatikan oleh pengambil kebijakan untuk selalu memenuhi kebutuhan pembejaran dan pendidikan supervisor ruangan dalam upaya meningkatkan kemampuan supervisi klinisnya.

c. Perbedaan Kemampuan Perawatan selama Penerapan Patient Centered Care Sebelum dan Sesudah Penerapan Supervisi Klinis Model Akademik pada Kelompok Intervensi dan Kelompok Kontrol

Hasil analisis kemampuan perawatan selama penerapan PCC sebelum penerapan supervisi klinis Model Akademik pada kelompok intervensi dan kelompok kontrol menunjukkan hasil yang kurang baik. Hasil analisis juga menunjukkan bahwa kemampuan perawatan selama penerapan PCC sebelum diberikan perlakuan pada kelompok intervensi memiliki rentang nilai 28 - 33 dengan nilai rata-rata 31,4615 sehingga masih diperlukan peningkatan 68,5385 untuk mencapai nilai maksimal kemampuan perawatan selama penerapan PCC oleh perawat.

Hasil analisis pada kelompok intervensi setelah perlakuan supervisi klinis Model Akademik oleh supervisor ruangan, terjadi peningkatan nilai rata-rata sebesar 11,1923 dengan nilai rata-rata 42,6538 dengan rentang nilai $37-45$, sehingga masih diperlukan peningkatan nilai 57,3462 untuk mencapai nilai maksimal terkait kemampuan perawatan selama penerapan PCC. Hasil ini walaupun tidak mencapai nilai sempurna, akan tetapi rata-rata mengalami peningkatan nilai sebesar 11,1923 dari nilai awal. Hasil analisis juga menunjukkan bahwa pada kelompok kontrol yang tidak dilakukan intervensi penerapan supervisi klinis Model Akademik terlihat tidak ada perbedaan bermakna antara sebelum dan sesudah perlakuan. Artinya hasil penelitian ini menunjukkan bahwa penerapan supervisi klinis Model Akademik oleh supervisor ruangan terbukti efektif dalam meningkatkan kemampuan perawatan selama penerapan PCC.

Hasil yang hampir sama didapatkan pada hasil analisis sebelum diberikan perlakuan pada kelompok kontrol yang menunjukkan bahwa kemampuan perawatan selama penerapan PCC tidak sesuai dengan panduan yaitu memiliki rentang nilai $28-35$ dengan nilai rata- 
rata 31,5200 sehingga masih diperlukan peningkatan 68,48 untuk mencapai nilai maksimal pelaksanaan perawatan selama penerapan PCC oleh perawat.

Hasil analisis pada kelompok kontrol yang diukur saat bersamaan sesudah kelompok intervensi menjalani perlakuan menunjukkan bahwa kemampuan perawatan selama penerapan PCC memiliki rentang nilai $32-37$ dengan nilai rata-rata 35,3200. Hal ini menunjukkan tidak terlalu signifikan perubahan yang terjadi jika dibandingkan dengan data hasil pengukuran awal karena hanya mengalami peningkatan sebesar 3,80 dari nilai awal.

Kemampuan perawatan selama penerapan PCC masih belum maksimal disebabkan oleh faktor individu dan faktor psikologi. Menurut peneliti, faktor individu meliputi umur, masa kerja, tingkat pendidikan serta faktor psikologis berupa motivasi. Umur responden dalam penelitian ini adalah rata-rata masih berusia muda yaitu berusia 29,23 tahun pada kelompok intervensi dan pada kelompok kontrol berusia 30,04 tahun. Usia muda dapat mempengaruhi kemampuan perawatan selama penerapan PCC yang kurang baik. Pernyataan ini dikuatkan hasil penelitian Anugrahini yang menyatakan bahwa perawat yang berusia rata-rata 34,4 tahun akan kurang patuh dalam melaksanakan tindakan, sedangkan perawat yang berusia 40,3 tahun akan patuh terhadap pedoman tindakan yang ditetapkan (Anugrahini, 2010). Umur yang semakin bertambah akan meningkatkan kebijaksanaan dan kemampuan seseorang dalam mengambil keputusan, berfikir rasional, mengendalikan emosi dan bertoleransi terhadap pandangan orang lain. Umur berkaitan dengan kedewasaan dan maturitas seseorang, semakin meningkatnya umur maka sikap kedewasaan akan berkembang sehingga meningkatkan pelaksanaan suatu tindakan.

Kurang baiknya kemampuan perawatan selama penerapan PCC disebabkan masa kerja yang masih kurang. Responden penelitian ini mempunyai masa kerja rata-rata 5,03 tahun pada kelompok intervensi dan mempunyai masa kerja rata-rata 5,91 tahun pada kelompok kontrol. Menurut peneliti, masa kerja kurang maka pengalaman perawat dalam melakukan tindakan pelayanan keperawatan kepada pasien juga kurang optimal, khususnya pada tindakan-tindakan yang berhubungan dengan keselamatan pasien dan penjagaan mutu pelayanan keperawatan. Hal ini diperkuat hasil penelitian Anugrahini yang menyatakan bahwa perawat yang patuh dalam menerapkan keselamatan pasien jika pada masa kerja rata-rata 17.3 tahun (Widiyanto, 2012). Menurut Siagian menyatakan bahwa semakin lama seseorang bekerja maka akan semakin terampil dan akan lebih berpengalaman dalam melaksanakan pekerjaan (Bindseil, 2008). Oleh karena itu masa kerja dapat memberikan gambaran tentang pengalaman kerja dan produktivitas sehingga meningkatkan kinerja seseorang.

Kemampuan perawatan selama penerapan PCC yang belum maksimal disebabkan oleh tingkat pendidikan. Responden dalam penelitian ini mempunyai jumlah mayoritas pendidikan D III, baik pada kelompok intervensi maupun kelompok kontrol. Menurut peneliti, responden dalam penelitian ini mempunyai tingkat pendidikan mayoritas DIII yaitu 23 orang $(45,1 \%)$ pada kelompok intervensi dan 22 orang $(43,1 \%)$ pada kelompok kontrol. Pernyataan ini dikuatkan oleh Dewi menyatakan bahwa perawat yang berpendidikan S1 akan menerapkan keselamatan pasien secara baik dengan 77,8\% dibandingkan dengan perawat yang berpendidikan D III sebanyak 48,5\% (Dewi, 2011). Hal ini menunjukkan semakin tinggi pendidikan maka semakin besar pula prosentase menerapkan keselamatan pasien dengan baik. Tingkat pendidikan lebih tinggi umumnya akan memiliki pengetahuan lebih luas, memiliki analisis terhadap suatu permasalahan yang baik sehingga lebih mampu dan bersedia menerima posisi dan tanggung jawab, serta 
dapat menerapkan dan mengaplikasikan pengetahuannya dalam bekerja.

Faktor lain yang menyebabkan pelaksanaan perawatan selama penerapan PCC masih kurang baik adalah motivasi perawat yang bersangkutan. Menurut peneliti, faktor motivasi sangat penting karena dapat mempengaruhi perilaku yang baik. Motivasi merupakan karakteristik psikologis manusia yang memberikan kontribusi pada tingkat komitmen seseorang. Pendapat tersebut diperkuat oleh penelitian Nur yang menyatakan bahwa ada hubungan signifikan antara motivasi dengan kinerja perawat dalam menerapkan keselamatan pasien. Semakin baik motivasi perawat, maka semakin baik pula kinerja perawat dalam melaksanakan suatu tindakan.

Rendahnya kemampuan perawatan selama penerapan PCC disebabkan beberapa faktor yang mempengaruhi perilaku. Hasil wawancara didapatkan data bahwa pengetahuan perawat terkait arti penting merawat dan mencegah kejadian tidak diharapkan demi kemampuan mutu yang baik. Hasil observasi terkait ketersediaan sarana, prasarana dan fasilitas yang mendukung perawatan selama penerapan PCC juga tersedia di ruangan. Faktor penguatlah yang menjadi kendala, rendahnya pemberian motivasi oleh supervisor ruangan, rendahnya kemampuan supervisor ruangan untuk melakukan tugas pokoknya yaitu supervisi klinis yang menyebabkan kemampuan perawatan selama penerapan PCC oleh perawat tidak maksimal dalam bekerja di ruangan. Menurut peneliti, faktor penguat (reinforcing factor) yang sangat berpengaruh dalam kurangnya kemampuan perawatan selama penerapan PCC yang dilakukan perawat di ruangan.

Analisis peneliti terkait kemampuan perawatan selama penerapan PCC yang kurang baik sebelum diberikan perlakuan juga disebabkan oleh supervisi klinis yang kurang optimal. Hasil observasi secara langsung pada kelompok intervensi dan kelompok kontrol sebelum perlakuan menunjukkan belum diterapkannya fungsi supervisi dengan baik dan efektif, misalnya supervisor ruangan hanya melakukan supervisi dalam bentuk morning report saat melaksanakan timbang terima dari shift malam ke shift pagi. Pelaksanaan supervisi belum menggunakan metode baku, belum terjadwal, tidak ada umpan balik dan tidak terdokumentasi, belum dilaksanakan secara continue, sehingga supervisi yang dilakukan belum dapat memberikan informasi yang objektif terkait pelaksanaan sesuai dengan standar yang berlaku.

d. Pengaruh Supervisi Klinis Model Akademik terhadap Peningkatan Kemampuan Perawatan dalam Penerapan PCC

Hasil analisis menunjukkan bahwa pada kelompok intervensi terjadi peningkatan nilai rata-rata 11,19 , sedangkan pada kelompok kontrol peningkatan nilai rata-rata hanya 3,8 . Hal ini membuktikan ada pengaruh supervisi klinis Model Akademik yang dilakukan kepala ruangan terhadap kemampuan perawatan selama penerapan PCC oleh staf perawat di RSU Mitra Siaga Tegal $(p=0,000)$.

Hasil penelitian ini mendukung penelitian lain terkait supervisi yang dilakukan oleh Rusmegawati bahwa pelaksanaan supervisi kepala ruang yang dinilai oleh perawat meningkat setelah dilakukan pelatihan (Budiyanto, 2013).

Kedua penelitian tersebut menegaskan bahwa pelaksanaan supervisi klinis yang baik merupakan retensi pengetahuan dan sikap positif yang terbentuk setelah pelatihan. Perbedaan supervisi klinis pada penelitian ini terjadi pada teknik pengumpulan data. Peneliti melakukan pengukuran supervisi klinis kepala ruangan menggunakan observasi dimana komponen supervisi klinis yang terdiri dari educative, supportive dan managerial harus dilakukan secara keseluruhan. Namun pada penelitian Rusmegawati pelaksaan 
kegiatan supervisi diukur menggunakan kuesioner berdasarkan persepsi perawat (Budiyanto, 2013). Pemilihan teknik pengukuran ini yang memungkinkan memunculkan perbedaan besaran hasil penenelitian dimana kedua teknik tersebut mempunyai keunggulan dan kelemahan masing-masing yang menentukan akurasi hasil pengukuran.

Pelaksanaan supervisi klinis kepala ruangan dalam penelitian ini mempunyai kategori baik. Kondisi ini terjadi karena adanya pelatihan supervisi klinik yang memberikan perubahan terhadap pengetahuan, sikap dan pada akhirnya perilaku kepala ruangan dalam menjalankan supervisi klinik model akademik untuk menjamin kualitas asuhan keperawatan. Kemampuan kepala ruangan dalam menjalankan supervisi klinik berhubungan dengan efektivitas supervisi klinik sesuai dengan hasil penelitian lain yang menyatakan bahwa terdapat hubungan yang bermakna antara efektivitas supervisi kepala ruangan setelah mendapat pelatihan supervisi dengan persepsi perawat pelaksana (Walsh, 2003).

Penelitian Karvinen dan Hyrkas terdapat perbedaan yang signifikan supervisi yang diberikan oleh orang yang mempunyai pengalaman dengan yang tidak mempunyai pengalaman. Pengalaman kepala ruangan pada penelitian ini selain pengalaman awal adalah adanya dilakukan pelatihan yang merupakan sebuah pembelajaran dirancang untuk memberikan pengalaman kepada kepala ruangan agar terjadi perubahan perilaku dalam melaksanakan kegiatan supervisi klinis (Bindseil, 2008).

Supervisor yang mempunyai pengalaman dapat memfasilitasi pertumbuhan baik pendidikan maupun pribadi yang di supervisi, sambil memberikan dukungan yang penting dalam mengembangkan otonomi klinis perawat pelakasan (Handoko, 2011). Supervisor yang berpengalaman mampu meningkatkan kualitas sumberdaya manusia. Hal ini berarti pelaksanaan supervisi oleh orang yang kompeten dapat menghemat biaya pengembangan bagi staf dan memastikan tersedianya suberdaya manusia yang kompeten sehingga dapat meningkatkan efisiensi dan efektivitas kualitas layanan. Namun, sumber daya harus diinvestasikan dalam pendidikan pengawas dan staf keperawatan perlu didorong untuk bekerja sama dengan pengawas sehingga dapat menimbulkan efek positif terhadap kepuasan kerja dan kualitas pelayanan (Cross, 2010).

Supervisi model akademik merupakan proses formal dari perawat profesional untuk memberikan support dan learning agar pengetahuan dan kompetensi perawat dapat dipertanggungjawabkan sehingga pasien mendapat perlindungan dan merasa aman selama menjalani perawatan (Smith, 2013). Proses formal dalam supervisi klinis ditandai adanya program supervisi secara rinci akan tetapi masih dapat disesuaikan dengan tingkat kemampuan perawat pelaksana, baik dari segi materi maupun waktu yang tersedia di ruangan.

Supervisi klinis ditandai dengan tingkat kepercayaan, dan tujuan supervisi klinis dapat berubah dari waktu ke waktu dan dalam berbagai situasi meskipun fokus supervisi klinis adalah pada pengembangan keterampilan klinis dan interpersonal individu yang disupervisi (Purnawanto, 2010). Kepala ruangan yang melaksanakan supervisi klinis dapat melakukan pembinaan yang direncanakan untuk membantu tenaga keperawatan dalam melakukan pekerjaan mereka secara efektif. Kemudahan teknik supervisi serta manfaatnya bagi perawat pelaksana sangat berkaitan dengan dilakukan supervisi klinis model akademik yang mempunyai fleksibilitas tinggi di seluruh layanan, baik dari sisi penentuan waktu maupun materi supervisi (Handoko, 2011). 
Supervisi klinis diarahkan untuk mengembangkan keterampilan klinis perawat pelaksana sehingga dapat meningkatkan kualitas pelayanan pada pasien (Walsh, 2003). Pelaksanaan supervisi yang baik sangat bermanfaat bagi staf keperawatan, terutama mereka bekerja dalam perawatan umum, perawat dengan status pegawai tidak tetap, kerja paruh waktu dan kerja shift dan memungkinkan semua perawat berperan aktif dalam kegiatan supervisi. Supervisi klinis juga memungkinkan perawat untuk mendiskusikan perawatan pasien di tempat yang aman, lingkungan yang mendukung, untuk meningkatkan pemahaman tentang isu-isu klinis (Cross, 2010).

\section{SIMPULAN DAN SARAN}

Simpulan

Kemampuan supervisi klinis sebelum diberikan pelatihan supervisi klinis Model Akademik pada kelompok intervensi sebesar 20,00 dan kelompok kontrol sebesar 17,50. Kemampuan supervisi klinis setelah diberikan pelatihan Model Akademik pada kelompok intervensi sebesar 23,33 dan kelompok kontrol sebesar 18,50.

Kemampuan perawatan dalam menerapkan PCC sebelum diberikan pelatihan supervisi klinis Model Akademik pada kelompok intervensi sebesar 31,46 dan kelompok kontrol sebesar 31,52. Kemampuan perawatan dalam menerapkan PCC setelah diberikan pelatihan supervisi klinis Model Akademik pada kelompok intervensi sebesar 42,65 dan kelompok kontrol sebesar 35,32.

Terdapat perbedaan kemampuan supervisi klinis sebelum diberikan pelatihan Model Akademik pada kelompok intervensi $(p=1.000)$ dan kemampuan supervisi klinis setelah diberikan pelatihan Model Akademik pada kelompok intervensi $(p=0.463)$. Terdapat perbedaan kemampuan perawatan dalam menerapkan PCC sebelum dan setelah diberikan supervisi klinis Model Akademik pada kelompok intervensi $(p=0.018)$ dan pada kelompok kontrol $(p=0.022)$.

Saran

Pihak rumah sakit selaku pemangku kebijakan diharapkan memberikan dukungan pelaksanaan supervisi klinik model akademik yang dilakukan oleh kepala ruang dan PCC yang dilakukan oleh perawat pelaksana dengan membuat Standar Prosedur Operasional (SPO) terkait. Pentingnya pendidikan berkelanjutan bagi perawat terutama manager keperawatan dan kepala ruang untuk mengembangkan kapasitas Sumber Daya Manusia (SDM) sehingga diperlukan perencanaan anggaran untuk mengadakan pelatihan supervisi klinis dengan metode supervisi klinik model akademik.

Kepala ruang disarankan memberikan pengarahan dan bimbingan pada saat melakukan supervisi dengan cara memberikan umpan balik (feedback) dan pembelajaran reflektif secara terus menerus untuk mempertahankan dan meningkatkan kualitas PCC. Penyelesaian masalah fokus pada satu masalah serta mendorong staf dalam mencari alternatif pemecahan masalah.

Perawat disarankan melakukan asuhan keperawatan dengan pendekatan $P C C$ sesuai dengan Standar Prosedur Operasional terkait (SPO).

\section{KEPUSTAKAAN}

Anugrahini C. (2010). Hubungan faktor individu dan organisasi dengan kepatuhan perawat dalam menerapkan pedoman Patient Safety di RSAB Harapan Kita Jakarta. Jakarta FK UI. Tesis. Diakses 5 juli 2016 dari http://lontar.ui.ac.id

Bindseil, K., et al. (2008). Clinical supervision handbook a guide for clinical supervisors for addiction and mental health. Toronto: Canada. 
Brunero, S., Parbury, \& Stein, J. (2008). The effectiveness of clinical supervision in an evidence based literatur review. Australian Journal of Advanced Nursing; vol 25 (3), 86-94.

Budiyanto A. (2013). Pengaruh Supervisi Klinik Model Akademik dan Kemampuan Menilai Prestasi Kerja Kepala ruang Terhadap Kepuasan Kerja Perawat Pelaksana di Ruang Rawat Inap, Tesis. Program Magister FIK. Depok: Universitas Indonesia. Tidak dipublikasikan.

Cross, W., Moore, A., (2010). Ockerby, S. Clinical supervision of general nurses in a busy medical ward of a teaching hospital. The Journal of Contemporary Nurse; vol 35 (2), 245-253.

Davis C \& Burke L. (2011).The effectiveness of clinical supervision for a group of ward managers based in a district general hospital: an evaluative study. Journal of Nursing Management.

Dewi SC. (2011). Hubungan fungsi manajemen kepala ruang dan karakteristik perawat dengan penerapan keselamatan pasien dan perawat di IRNA I RSUP dr. Sardjito Yogyakarta. Tesis. Universitas Indonesia.

Drenkard, K, et all. (2013). American Association of Colleges of Nursing.

Farington, A. (1995). Models of clinical supervision. British Journal of Nursing; vol 4 (15), 876-878.

Frampton, S, et all. (2008). Patient Centered Care Improvement Guide. Inc. and Picker Institute.

Gillies, D.A. (1996). Nursing management: A system approach (3 ${ }^{\text {rd }}$ ed.). Philadelphia: W.B. Saunders Company.

Hasibuan, Malayu S.P. (2006). Manajemen Dasar, Pengertian, dan. Masalah,Edisi Revisi, Bumi Aksara:Jakarta.

Handoko, T.H. (2011). Manajemen (edisi 2). Yogyakarta: BPFE.

Keliat BA, Akemat. (2012). Model praktik keperawatan professional jiwa. EGC, Jakarta.

Kementerian Kesehatan Republik Indonesia. (2009). Undang - Undang No.36 Tentang Kesehatan. Indonesia.

Kurniadi K \& Irianto J. (2007). Prinsip-Prinsip Dasar Manajemen Pelatihan. Bandung.

Lynch, L., Hancox, K., Happell, B., \& Parker, J. (2009) Clinical supervision for nurses. United Kingdom: Wiley-Blackwell.

Marquis BL \& Huston CJ. (2012). Leadership role and management function in nursing, theory and applications. ed.7. Philadelphia: Wolter Kluwer Lippincot William Wilkins.

Nursalam. (2015). Manajemen Keperawatan Aplikasi dalam Praktik Keperawatan Profesional Edisi 5. Jakarta: Salemba Medika.

Purnawanto, B. (2010). Manajemen SDM berbasis proses. Jakarta: Grasindo. 
Rusmawati A. (2016). Upaya Meningkatkan Kemampuan Perawat dalam Menerapkan Patient Centered Care (PCC) di Rumah Sakit, Tesis. Program Magister FK. Undip : Semarang.

Saifulloh. (2009). Pengaruh pelatihan asuhan keperawatan dan supervisi terhadap motivasi kerja dan kinerja perawat pelaksana di Ruang Rawat Inap RSUD Indramayu. Tesis FIK UI (Tidak dipublikasikan).

Serio IJ. (2014). Using Coaching To Create Empowered Nursing Leadership To Change Lives. Contin Educ Nurs. doi:10.3928/00220124-20140103-14.

Siagian S. (2009). Pengembangan Sumber Daya Manusia. Jakarta: Rineka Cipta.

Sloan, G., \& Watson, H. (2002) Clinical supervision models for nursing: structure, research and limitations. Nursing Standard vol 17 (4), 41-46.

Smith, K.L. (2013). A brief summary of supervision models; 2009. March 7, 2013. http://www.gallaudet.edu/documents/academic/cou_supervisionmodels.

Sulistyani AT \& Rosidah. (2009). Manajemen sumber daya manusia: konsep, teori dan pengembangan dalam konteks organisasi publik. Yogyakarta: Graha Ilmu.

Uys, L.R., Minnaar, A., Simpson, B., \& Reid, S. (2005). The effect of two models of supervision on selected outcomes. Journal of Nursing Scholarship; vol 37 (3), 282-288.

Walsh, K., J. Nicholson, et al. (2003). Development of a group model of clinical supervision to meet the needs of a community mental health nursing team. International Journal of Nursing Practice, 9(1): 33-39.

Widiyanto, Puguh. (2012). Pengaruh pelatihan supervisi terhadap penerapan supervisi klinik kepala ruang dan peningkatan kualitas tindakan perawatan luka di RSU PKU Muhammadiyah Temanggung. Tesis. Universitas Indonesia. 